Estonian Journal of Archaeology, 2019, 23, 1, 56-72

https://doi.org/10.3176/arch.2019.1.04

Beata Miazga, Pawel Milejski, Sylwia Rodak, Alicja Rafalska-Łasocha and Marta Grzesiak-Nowak

\title{
MICROSCOPIC AND SPECTROSCOPIC STUDIES OF POTTERY FOUND IN THE PRAGUE GROSCHEN HOARD FROM THE AREA OF WALBRZYCH - CONFIRMING COMPATIBILITY BETWEEN THE CERAMIC VESSELS AND THE COINS
}

The initial classification of numismatic finds consists mainly in determining whether they were single finds, hoards or cumulative deposits. In the course of the last few decades the availability of metal detectors increased significantly, and more and more hoards are found by amateurs. In such situations, especially when hoards include coins, one must be very careful and all possibilities must be thoroughly considered. In such situations suitable research techniques must be employed in order to verify the genuineness of the artefacts, the coins and the containers in which they were deposited. The available research methods must be utilized to determine whether the size of the vessel matched the number of the coins recorded, if there were any coin traces inside of the vessels in which they had allegedly been deposited and if matching patina/corrosion traces occur both on the coins and in the vessels. This investigation was realized for the hoard of Prague groschen recorded in the vicinity of Wałbrzych (Lower Silesian province, Poland), which was accidentally found. For this purpose, the non-destructive methods were applied, including the infrared spectroscopy (FT-IR), X-ray diffraction and fluorescence (XRD, XRF) and microscopic studies $(\mathrm{OM})$.

Beata Miazga, Institute of Archaeology at the University of Wrocław, 48 Szewska St., 50-139 Wrocław, Poland; beata.miazga@uwr.edu.pl

Paweł Milejski, Institute of Archaeology at the University of Wrocław, 48 Szewska St., 50-139 Wrocław, Poland; pawel.milejski@uwr.edu.pl

Sylwia Rodak, Institute of Archaeology at the University of Wrocław, 48 Szewska St., 50-139 Wrocław, Poland; sylwia.rodak@uwr.edu.pl

Alicja Rafalska-Łasocha, Faculty of Chemistry, Jagiellonian University, 24 Gołębia St., 31-007 Kraków, Poland; alicja.rafalska-lasocha@uj.edu.pl

Marta Grzesiak-Nowak, Faculty of Chemistry, Jagiellonian University, 24 Gołębia St., 31-007 Kraków, Poland; marta.grzesiak@uj.edu.pl 


\section{Introduction}

The initial classification of numismatic finds mainly means determining whether they were single finds, hoards or cumulative deposits (Grierson 1975, $125 \mathrm{ff}$.). Find circumstances determine their classification as chance finds and finds recorded during the regular archaeological excavations ${ }^{1}$. Moreover, special attention must be paid to items devoid of archaeological context, which give rise to doubts already at the point of their accidental discovery.

In the course of the last few decades the availability of metal detectors increased significantly, and more and more hoards are found by amateurs. According to the current Polish legislation ${ }^{2}$ the use of metal detectors is forbidden without a permission issued by the authorities responsible for heritage protection (even in the case of regular archaeological excavations). Since 2015 a considerable increase in the number of accidental archaeological finds has occurred. According to statistics, 19 such cases were recorded in 2015, while in the following year 32 applications were registered (Wawrzczak 2017, 57 f.). However, in many cases the genuineness of the finds seems questionable. The finder might have well fabricated the deposit by putting coins from one find into vessels from another. In such situations, especially when hoards include coins, one must be very careful and all possibilities must be thoroughly considered. Coin hoards, besides of their indisputable historical importance, are very often of high monetary value. The assemblage of a few hundreds, and sometimes a few thousands of coins, often made of high-quality bullion, might be worth even more than 100000 PLN. In such situations suitable research techniques must be employed in order to verify the genuineness of the artefacts, the coins and the containers in which they were deposited. The available research methods must be utilized to determine whether the size of the vessel matched the number of the coins recorded, if there were any coin traces inside of the vessels in which they had allegedly been deposited and if matching patina/corrosion traces occur both on the coins and in the vessels.

The accidentally found hoard of Prague groschen recorded in the vicinity of Wałbrzych, Lower Silesian province, Poland, constitutes a very interesting find (Fig. 1). The numismatic analysis demonstrated that the coins were struck mostly during the reign of Wenceslas IV (1378-1419) - as many as 1310 coins with only 75 specimens struck under Charles IV (1346-1378). The groschen of Wenceslas IV constitute $94 \%$ of the hoard, while coins of his predecessor on the Bohemian throne make only a minor, $5 \%$ admixture. This shows clearly that the hoard was deposited in the second half of the Wenceslas reign, that is no sooner than at the turn of the 14th and 15th centuries. Deposits dated to the initial years of the Bohemian king reigns always contain large percentage of groschen struck under

1 For more information on the classification of numismatic finds see Kiersnowski 1958, $181 \mathrm{ff}$; Tabaczyński 1987, 89 ff.; Suchodolski 2012, 260 ff. Further reading also there.

2 Act on Monument Protection and Maintanance (Ustawa o Ochronie Zabytków i Opiece nad Zabytkami) of 23rd July 2003; Criminal Code; Journal of Laws. 2003, No. 162, pos. 1568. 


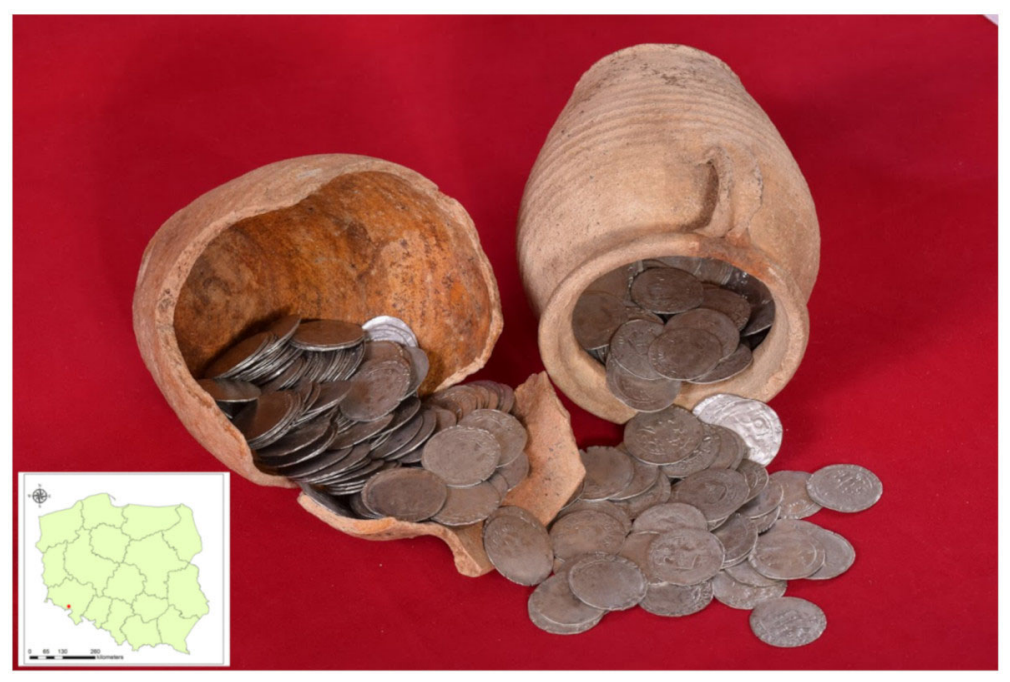

Fig. 1. Hoard of the Prague groschen found in the Wałbrzych area (Lower Silesia, Poland).

the king's predecessor - or predecessors. On the contrary, hoards deposited in the latter half of the reign included only a minor mixture of some better groschen issued by the predecessor (1-5\%) (Castelin 1953, $51 \mathrm{f}$.). Coins of high silver content - not depreciated yet - were intentionally selected and removed from circulation (Kisielewski 1971, 65 ff.). The available catalogues of the Prague groschen struck under Charles IV and Wenceslas IV (Hána 2003; Pinta 2005) make an initial dating of the Wałbrzych hoard to the 2nd and 3rd decade of the 15 th century possible.

The hoard in question was deposited in two ceramic pots. This provoked a discussion on the problem of ceramic vessels found in hoards. In late medieval and modern times ceramic containers were often used to preserve and hide precious items, especially coins. Technological and stylistic analysis of the ceramic vessels complemented with the numismatic analysis allows for a precise determination of their chronology. Coins deposited in the pot constitute a closed assemblage, in which the latest coin determines the terminus post quem of the deposition (Mikołajczyk 1977, 11 ff.). The existing studies on the ceramic vessels found in hoards indicate that in the late medieval and modern times pottery deposited in hoards represented types commonly used at a certain time. No selection of forms and ornamentation was made. The person preparing the deposit aimed first and foremost to properly protect the coins in undamaged containers. The initial analyses suggest that such forms were utilized for a relatively short period of time (Mikołajczyk 1977, 13).

One of the vessels containing the Prague groschen from area of Wałbrzych was undamaged, the other one was reconstructed. Technological and stylistic features of the analysed forms are typical of the late medieval pottery making from 
the turn of the 14th and the 15th centuries. Both were made on fast potter's wheel with the use of coiling and turning technique of clay tempered with sand grains. They were fired in oxidizing conditions, so that a cream colour was obtained. Their bottoms are featured with faint regular lines, which indicate that the vessels were separated from the axis of the potter's wheel with a wire. Such production technology is parallel to technologies used in the pottery production in the nearby Świdnica and Dzierżoniów, where such pottery is dated to the final part of the 14th and the first half of the 15th century (Boguszewicz \& Daszkiewicz 1999, 517; Karst \& Lasota 2000, 262 f.; Boguszewicz 2004, 134 f., fig. 13h-j, m; 2009, 27, fig. 18).

\section{Research methods}

In order to determine whether the coins might have been deposited in the vessels, archaeometric studies with the use of non-destructive analytical techniques have been conducted. Those were first and foremost spectroscopic methods, such as the XRF and XRD analyses, as well as infrared spectroscopy. Such techniques are widely used in studies of archaeological finds (Moropoulou et al. 2000; Giumlia-Mair 2005; Genestar et al. 2006; Akyuz et al. 2007; Pitarch et al. 2011; Teoh et al. 2014; Angeli et al. 2018; Palmer et al. 2018). Moreover, metric measurements of the coin assemblage and both vessels have been performed and their total volume/capacity calculated. Microscopic observations of the ceramic vessels have also been made.

The energy-dispersive X-ray fluorescence analysis (XRF) has been conducted with the use of Spectro Midex spectrometer featured with a molybdenum X-ray tube and an SDD semiconductor detector cooled with the Peltier Effect. The energy resolution (FWHM) did not exceed $100 \mathrm{eV}$. The excitation energy was $44.6 \mathrm{kV}$, the amperage $0.3 \mathrm{~mA}$. The study has been conducted according to the Fundamental Parameters Program method, which allows for both qualitative and semiqualitative analyses.

The samples were analysed by means of Fourier-transform infrared spectroscopy (FT-IR) with the use of Thermo Nicolet 380 device. The analyte was mixed with spectrally pure potassium bromide in $1: 200$ proportion and compressed into a disc with a hydraulic press using a 10-ton load. Thereafter the disc was analysed in the spectral range of $4000-400 \mathrm{~cm}^{-1}$ and with a resolution of $4 \mathrm{~cm}^{-1} .16$ scans of the sample have been made.

The X-ray powder diffraction analyses (XRPD) have been conducted with the use of Panalytical X'pert pro MPD diffractometer. The measurements have been taken in the diffraction-angle range of $4.0-90.0^{\circ} 2 \theta$. The $\mathrm{CuK} \alpha$ tube worked at $40 \mathrm{kV}$ voltage and $30 \mathrm{~mA}$ cathode current. The obtained diffractograms has been analysed with the use of X'pert HighScore programme and the PDF-4 + 2014.1 database (ICDD, USA). 
Microscopic observations have been conducted with the use of light microscope OLYMPUS SZX9 at 6.3-63 x magnification and the Hirox RH2000 digital microscope with $20-180 \mathrm{x}$ objective. The 3D models were developed in the Institute of Archaeology at University of Wroclaw with the 3D Konica Minolta Vivid-910 scanner and the INUS Rapidform XOS2 programme (scanning and processing) to make the calculations of vessel capacities as precise as possible.

\section{Results and discussion}

\section{Determining vessel capacities and coin volumes}

The measurements of ceramic vessel capacities were conducted in two ways. The first method used scaled images of the vessels, which were used for further mathematical calculations. Dividing vessels into many truncated cones has long been used to calculate pot capacities (Thomas \& Wheeler 2002) and is based on the following formula:

$$
V=\frac{\pi}{3} h\left(R^{2}+R r+r^{2}\right) .
$$

The data used in the calculation was obtained through the GIMP image editing software, which is demonstrated on Fig. 2a. It is more of an estimation than a precise measurement since graphically processed images of the vessel are not their ideal (faithful) representation. Capacity measurement of each of the vessels was conducted by matching horizontal vessel fragments with $1 \mathrm{~cm}$ high truncated cones. The total vessel capacity was calculated as a sum of the capacities of all fragments. As shown in Fig. 2 a vessel No. 1 was divided into 12 and vessel No. 2 into 14 fragments. The walls were ca $8 \mathrm{~mm}$ and $4 \mathrm{~mm}$ thick respectively. According to the mathematical calculation the capacities of the medieval vessels were $555 \mathrm{~cm}^{3}$ (vessel No. 1) and $809 \mathrm{~cm}^{3}$ (vessel No. 2). This gives an estimated total capacity of $1364 \mathrm{~cm}^{3}$.

The second method is more objective and gives more reliable results. In this calculation of the vessel capacities, 3D models of the artefacts were utilized (Fig. 2b). In the first step a section was made through the vertical axis of the vessel and thereafter cross-sections at regular intervals perpendicularly to the vertical axis (6.6 and $5.3 \mathrm{~mm}$ in vessel No. 1 and $5.0 \mathrm{~mm}$ in vessel No. 2). In this way a metric measurement grid was obtained, on which diameters and radials (in the incomplete vessel No. 2) were measured along the vertical axis. After calculating the volumes of the multiple truncated cones, capacities of 675 and $923 \mathrm{~cm}^{3}$ were obtained for vessels 1 and 2 respectively. The total capacity of the vessels was thus $1598 \mathrm{~cm}^{3}$. 
a
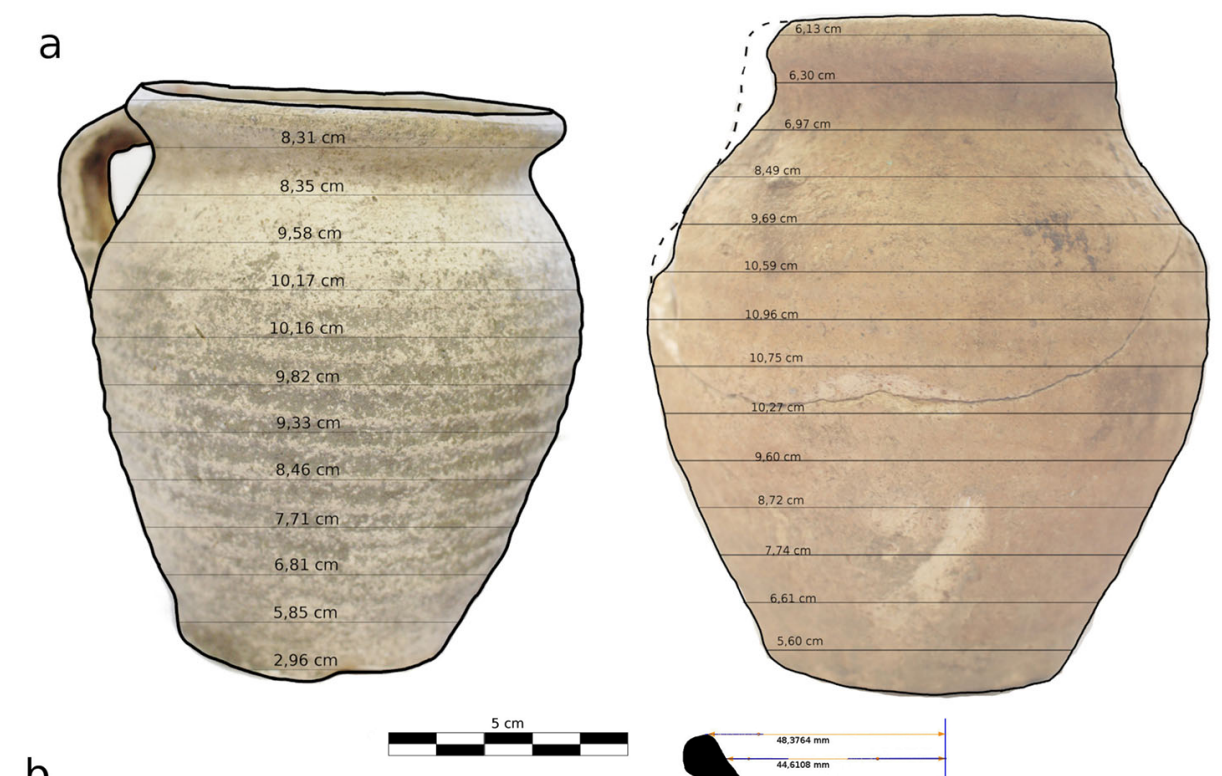

b

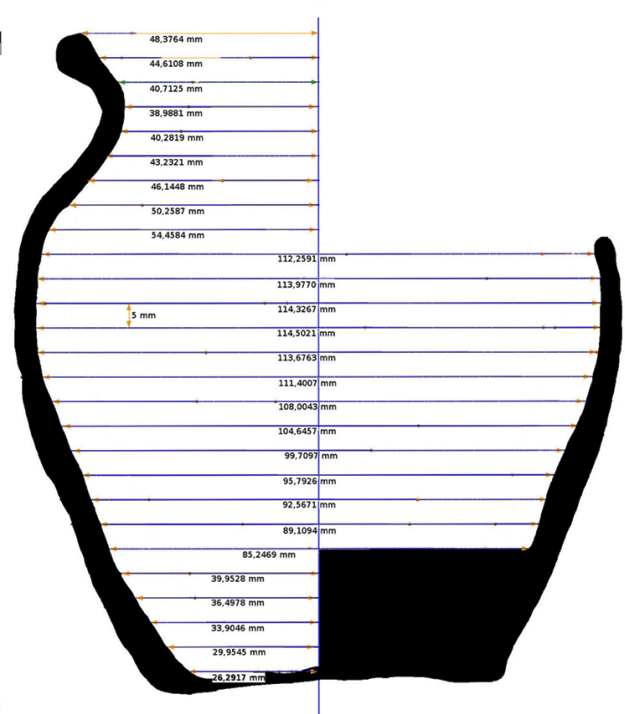

Fig. 2. Ceramic vessels from the hoard. a - scaled images of the ceramic vessels in which the coins were deposited (dashed line represents the potential shape of the missing part of vessel No. 2), $\mathrm{b}$ - vertical sections obtained from 3D models.

The mean volume of the groschen assemblage (Table 1) was calculated as a mean cylinder volume obtained after measuring fifteen specimens of the groschen, multiplied by the number of the coins in the hoard - that is 1385 . The total coin volume obtained in this way was below $600 \mathrm{~cm}^{3}$, which is over $1000 \mathrm{~cm}^{3}$ less than the total vessel capacity and proves that the groschen might have possibly been deposited in the vessels. 
Table 1. The results of coin volume calculations

\begin{tabular}{l|c|c|c}
\hline The coin number & Thickness, $\mathrm{h}[\mathrm{cm}]$ & Diameter, $\mathrm{d}[\mathrm{cm}]$ & $\mathrm{V}=\pi / 4 *(\mathrm{~d})^{2 *} \mathrm{~h}$ \\
\hline 35II & 0.07 & 2.78 & 0.4247 \\
33II & 0.07 & 2.71 & 0.4036 \\
19I & 0.07 & 2.74 & 0.4125 \\
14I & 0.08 & 2.74 & 0.4715 \\
30I & 0.07 & 2.73 & 0.4095 \\
8I & 0.06 & 2.81 & 0.3719 \\
5I & 0.07 & 2.74 & 0.4125 \\
4I & 0.07 & 2.70 & 0.4006 \\
3I & 0.07 & 2.70 & 0.4006 \\
2I & 0.07 & 2.74 & 0.4125 \\
7I & 0.07 & 2.72 & 0.4065 \\
16I & 0.06 & 2.84 & 0.3799 \\
12I & 0.07 & 2.78 & 0.4247 \\
58II & 0.07 & 2.79 & 0.4277 \\
38II & 0.07 & 2.82 & 0.4370 \\
Average $\left[\mathrm{cm}^{3}\right], \mathrm{n}=15$ & & 0.4131 \\
The total amount of the Prague groschen & & 1385 \\
The total volume of the hoard $\left[\mathrm{cm}^{3}\right]$ & & 572.08
\end{tabular}

\section{Microscopic studies}

Microscopic observations of the vessels were mostly conducted on their inside and focused on identifying potential traces of coins. Observations of the bottom and inner walls were especially challenging in the case of the fully preserved vessel (vessel No. 1). In spite of the difficulties it was possible to obtain images which definitely confirmed the presence of greenish residues on the ceramic base contaminated with layers of soil (Fig. 3). Seen in $20 \mathrm{x}$ magnification the green spots were visible as 100-200 micrometre structures, often of elaborated shape.

Studying vessel No. 2 in 6.3 x magnification resulted in interesting observations: inside of the vessel three circular outlines were identified. Their dimensions - 26.9 and $24.1 \mathrm{~mm}$ - matched the sizes of the Prague groschen (Fig. 4). Observations were continued in greater magnification, which allowed to identify blue-greenish deposits on the wall and bottom of the vessel. The structures seen in $140 \mathrm{x}$ magnification proved to be well mineralized residues (Fig. 5).

\section{Spectroscopic studies}

The spectroscopic analyses were conducted on the sample of the deposits scratched from the inside of vessel No. 1 (sample No. 1) and the corrosion layers obtained during the conservation of four randomly selected groschen. Mechanic cleaning with the use of abrasive tools provided small samples of corrosion, which were homogenized (sample No. 2). The spectroscopic analyses aimed to determine and compare the chemical composition of the samples. 

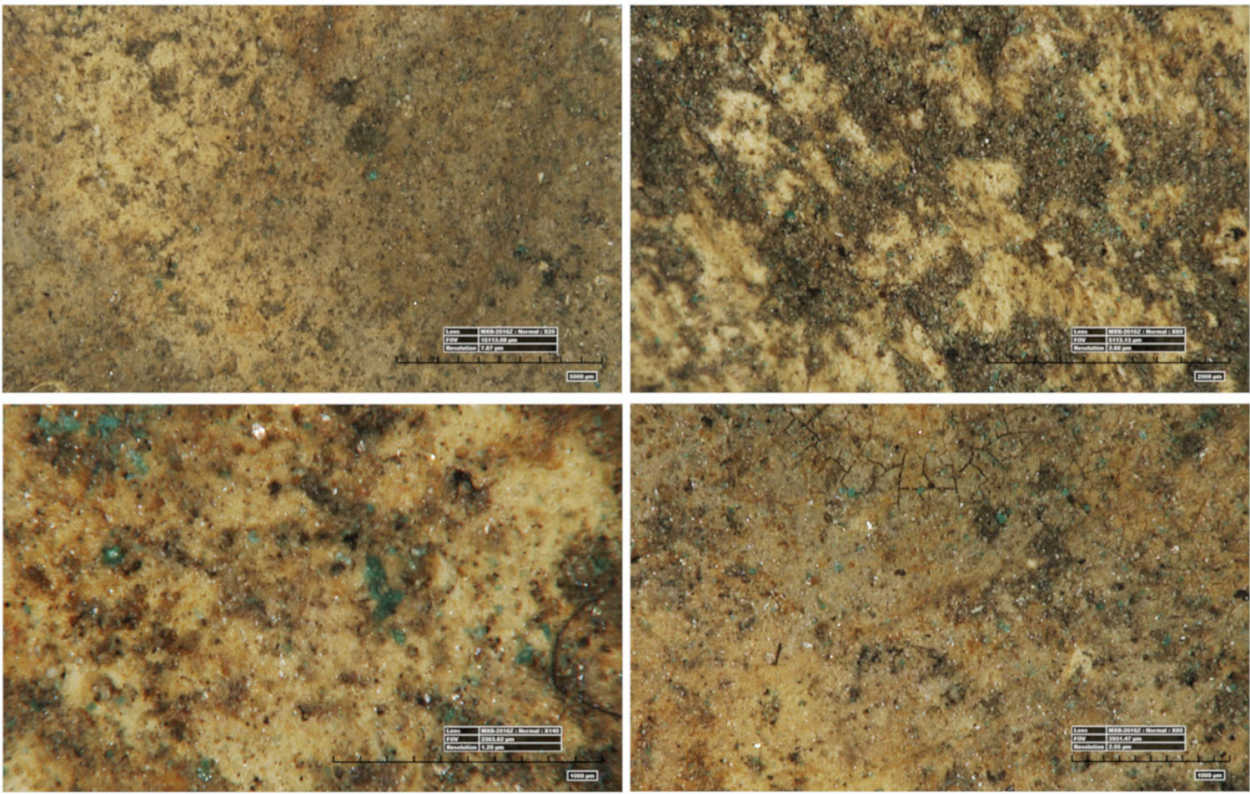

Fig. 3. Microscopic images of the inside of vessel No. 1 with visible greenish residues.
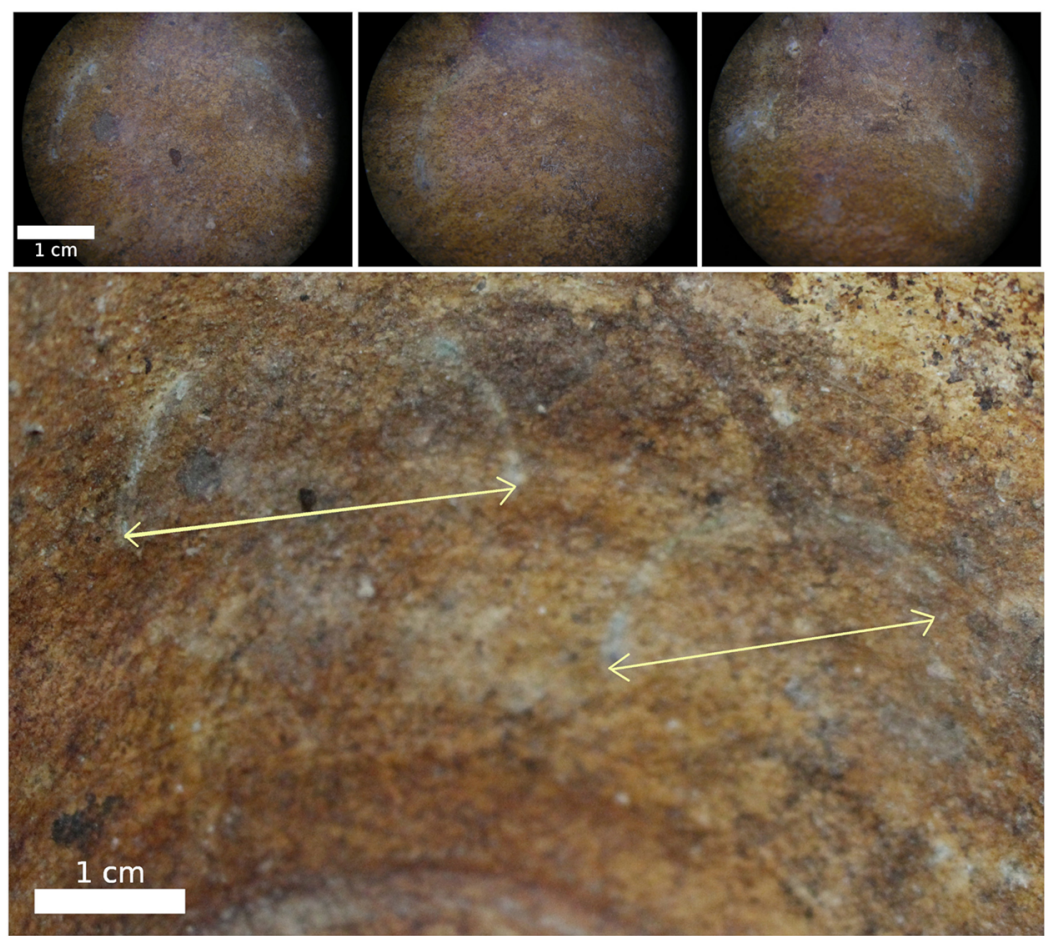

Fig. 4. Vessel No. 2. Coin outlines visible on the inner side of the vessel (optical microscopy, $6.3 \mathrm{x}$ ). 

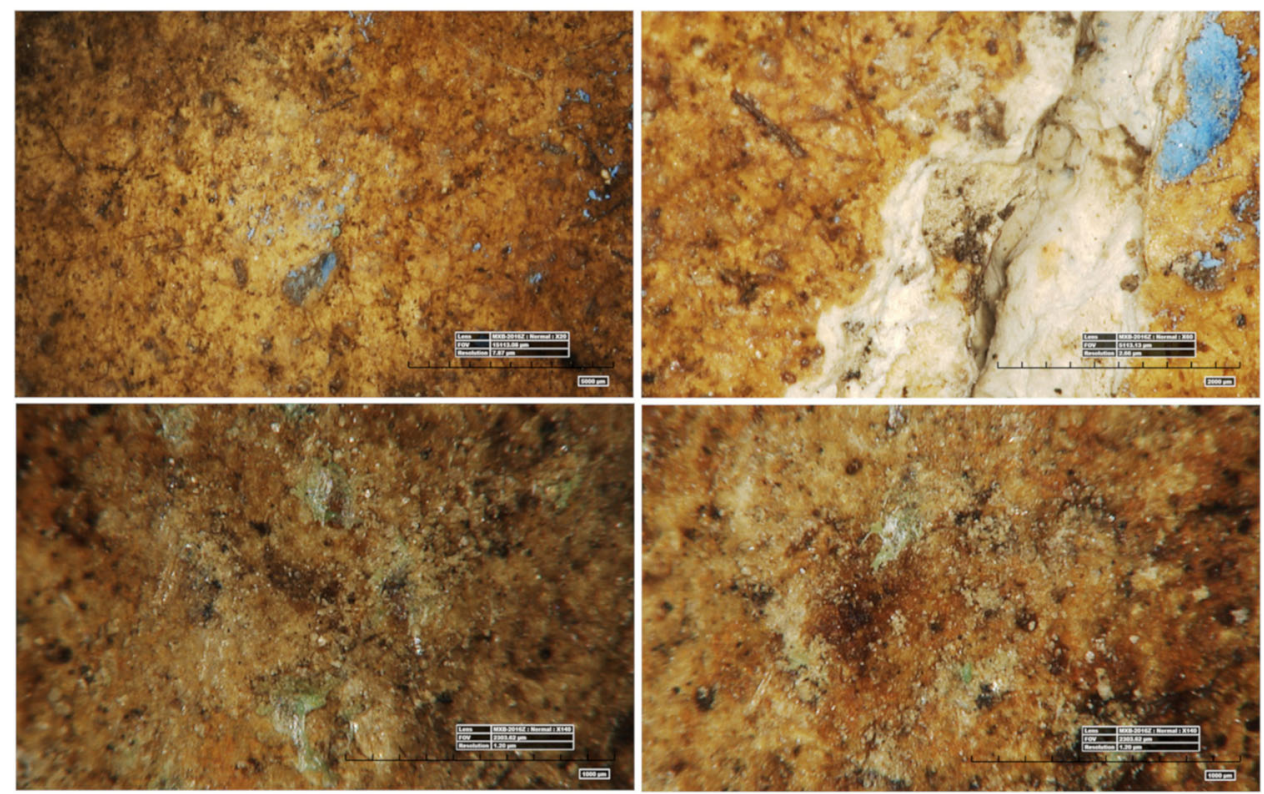

Fig. 5. Vessel No. 2. Blue-green residues visible on the inner side of the vessel (light microscopy, 20-140 x magnification).

The XRF analyses demonstrated that both samples contained very intense copper signals. Moreover, in sample No. 1 weaker signals of iron, manganese, lead, silver, titanium, calcium, potassium and silicon were detected (Fig. 6a). In addition to copper, the sample taken from the groschen corrosion layer displayed strong signals of silver and less intense signals of iron, titanium and silicone. The level of lead signals is comparable to the level observed in sample No. 1 (Fig. 6b). The mutual similarity of the samples cannot be excluded due to the presence of copper in both. Furthermore, infrared spectroscopic analyses identified malachite in both samples. In sample No. 1 the malachite signals were weaker, since it was a mixture consisting mostly of illite (hydrated potassium aluminium silicate) and thereafter quartz and clay containing quartz (Fig. 7). The sample taken from the groschen corrosion layer was much purer with malachite constituting its main ingredient. When compared to a sample of this mineral from Gelnica (Slovakia), the affinity index was over $80 \%$ (Fig. 8). Additionally, intense peaks on the spectrum indicate a significant content of basic copper carbonate in the analysed sample.

The X-ray diffraction is the most informative of the analytical tools used in the study, as it provides information on the phase composition of the analysed samples. In the course of the analytical procedure it has been demonstrated that sample No. 1 besides of the malachite contains quartz and merlinoite (hydrated potassium calcium aluminosilicate). Unfortunately, the diffractogram (Fig. 9) does 
not show silver compounds. Nevertheless, their presence cannot be excluded since the diffraction peaks of malachite and silver oxide (I) are located very close to each other. In the second of the analysed samples malachite and metallic silver were identified (Fig. 9).

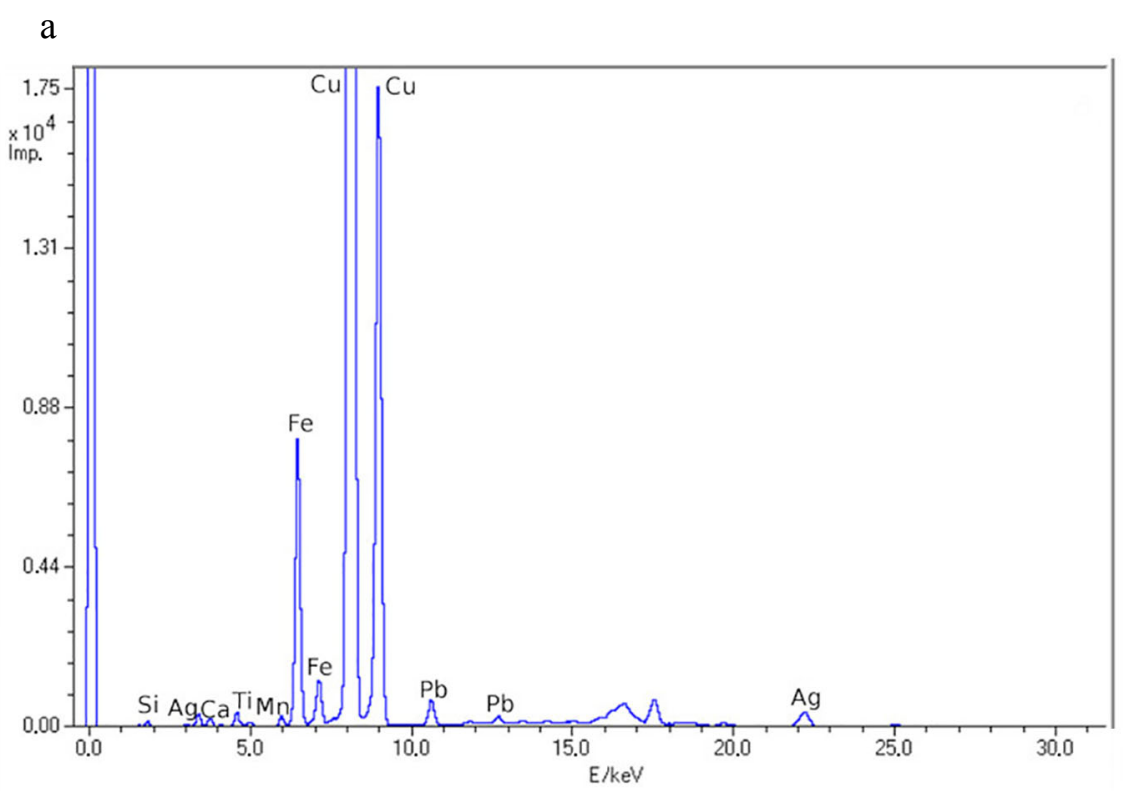

b

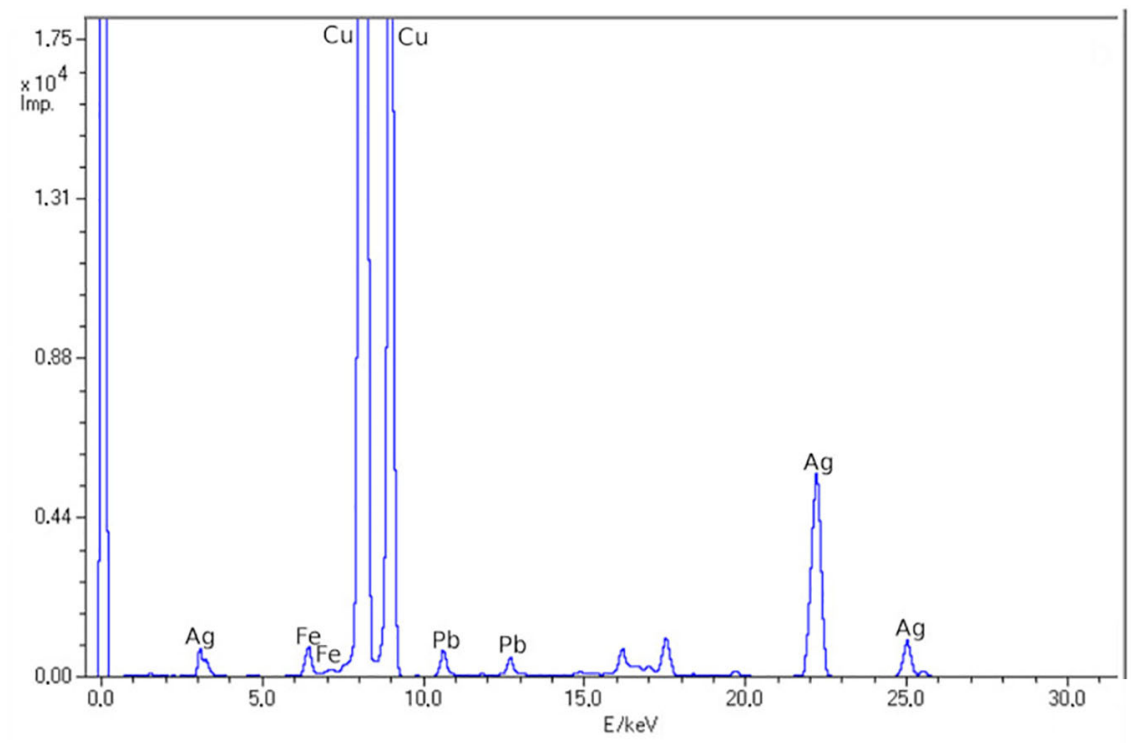

Fig. 6. XRF energy spectra. a - sample No. 1 (scratched from the inside of the vessel), copper, iron, lead and silver signals visible, b - sample No. 2 (corrosion layer from the Prague groschen), copper, silver and lead signals detected. 


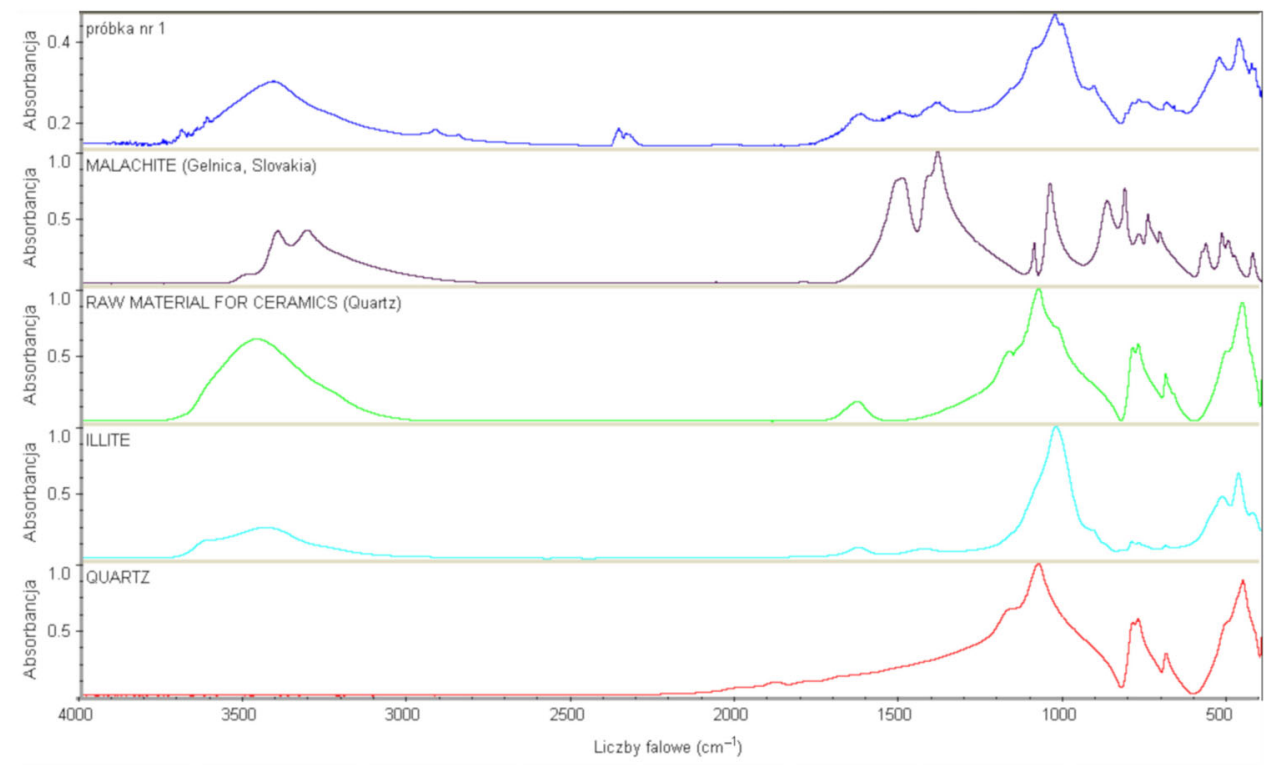

Fig. 7. Comparison of the infrared spectra in sample No. 1 (scratched from the inside of the vessel) and spectra from the Inorganic Library HR. Presence of silicate minerals, quartz and malachite in the sample confirmed.

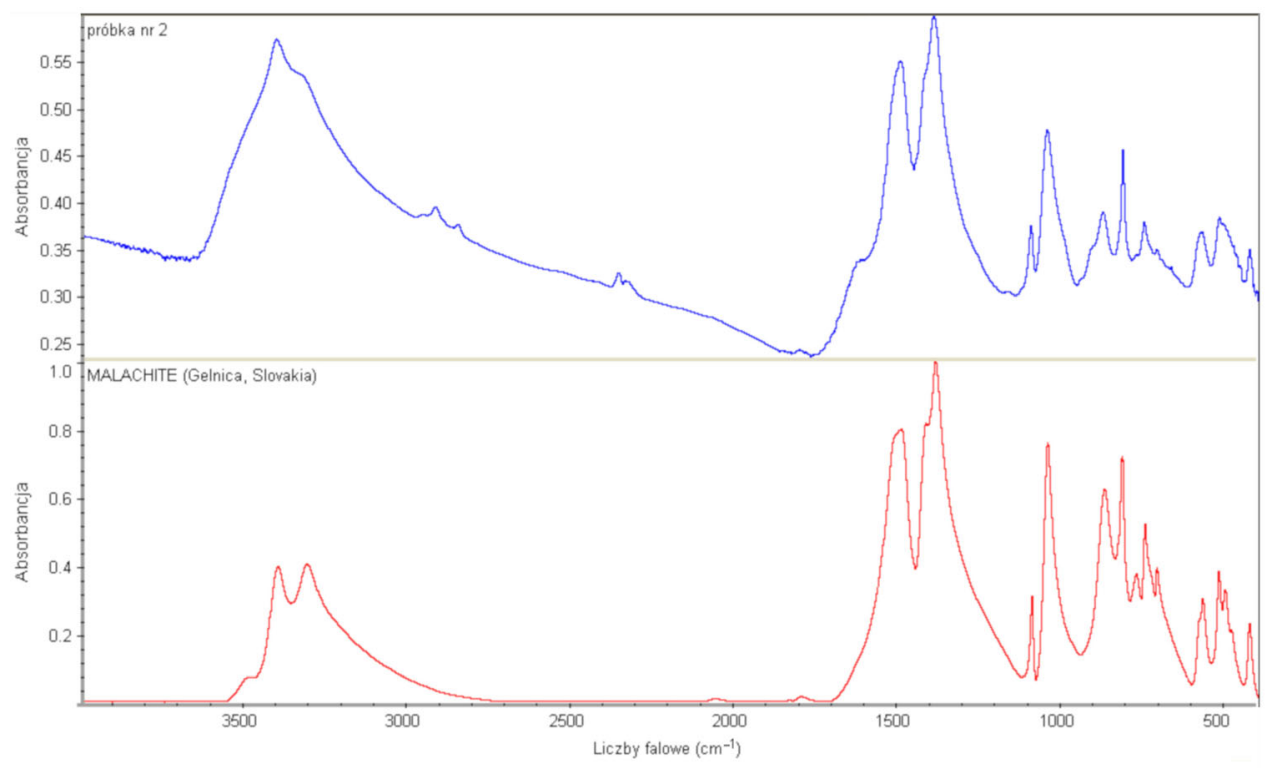

Fig. 8. Comparison of the infrared spectra in sample No. 2 (corrosion layer of the Prague groschen) and spectra published in the literature (Inorganic Library HR). Large quantities of malachite identified in the sample. 
a

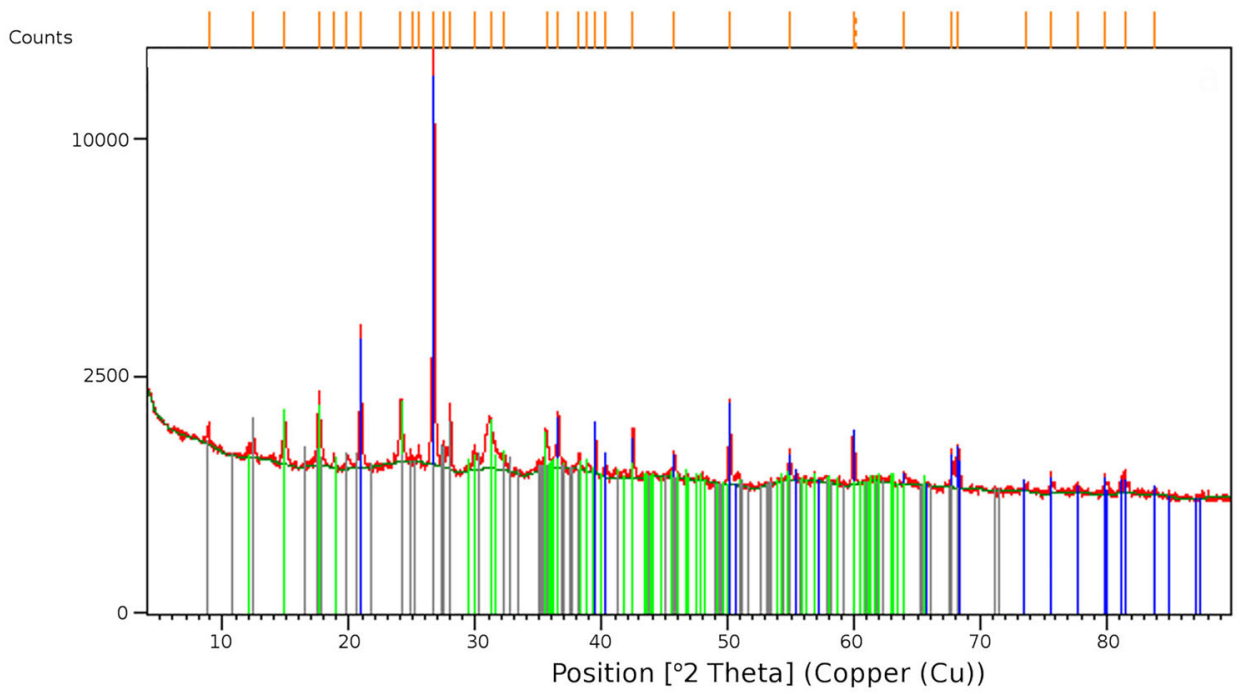

b

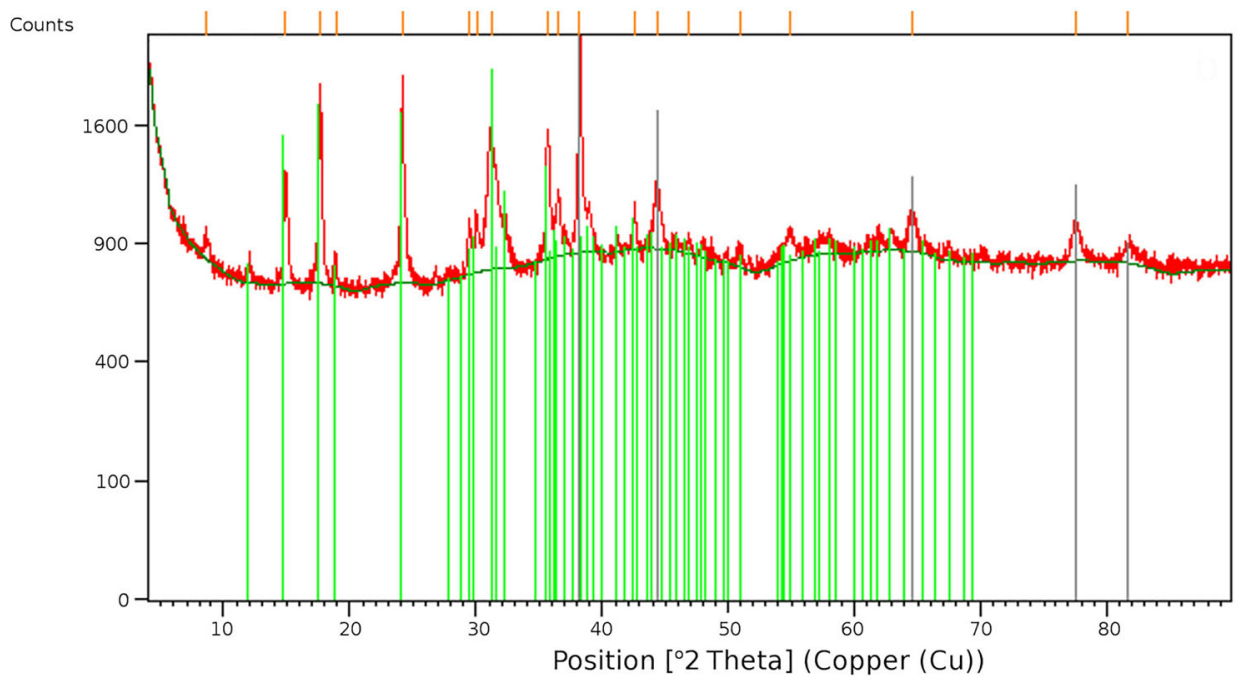

Fig. 9. Diffractograms. a - sample No. 1, presence of malachite (green lines), quartz (blue lines) and merlinoite (grey lines), b - sample No. 2, malachite (green lines) and metallic silver (grey lines identified).

As vessel No. 2 contained much less contaminations it was difficult to obtain sufficient samples without leaving visible traces on the artefact. A set of spectral images obtained in the course of the qualitative XRF analyses allows for a comparison of the intensity of copper signals (Fig. 10) which amount to 1259 and 4284 impulses in samples taken respectively by scratching the inner surface of 


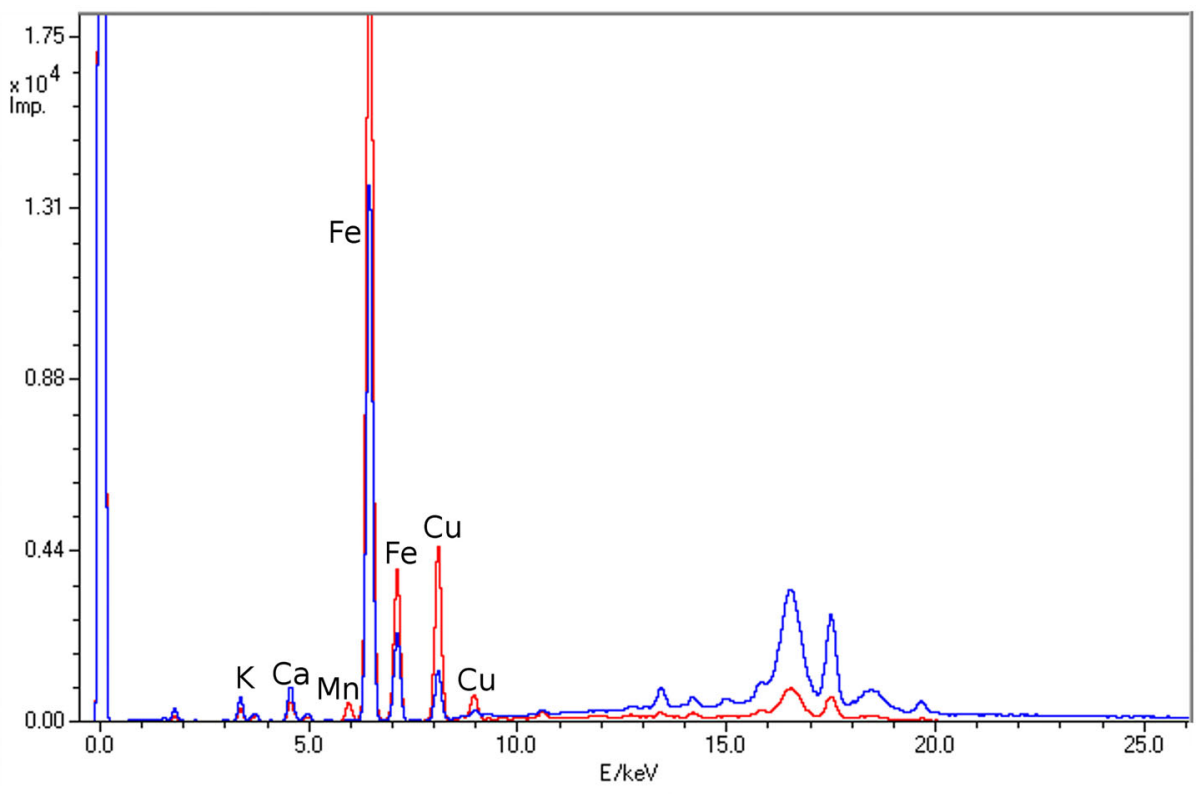

Fig. 10. Vessel No. 2. Comparison of the XRF spectral images of the sample scratched from the inside of the vessel (red line) with studies of the fracture surface of the ceramic vessel (blue line).

the vessel and from the vessel's fracture surface. On the other hand, the analyses of a bluish-coloured spot (identified through microscopic observations) provided numerical data, which indicate a significant iron content (ca 36\%) and almost $9 \%$ copper content (the remaining $40 \%$ are non-analytical signals from light elements or spectrometer's parts). However, the fresh vessel fracture, apart from strong iron signals $(2.28 \% \mathrm{Fe})$, contained almost $0.1 \%$ copper. The rest were light elements, which occur in clay (mostly $\mathrm{Si}, \mathrm{Al}, \mathrm{O}, \mathrm{Ca}, \mathrm{K}$ ). This demonstrated that the bluish residues inside of the vessel were copper compounds - and more precisely corrosion products of the silver-copper coins. Due to small size of the sample no further spectroscopic analyses have been conducted.

\section{Summary}

The archaeometric data provided by both of the samples demonstrated that the coins were deposited in the vessels. The calculated capacity of the vessels was much greater than the total volume of the groschen placed on one another, so that they would form a cylinder. In addition to the matching capacity of the vessels and traces of coin corrosion products inside of them, copper was identified as the main ingredient in the samples. The results of the elementary XRF analysis of sample No. 1 (taken from the ceramic vessel No. 1) detected also presence of iron, 
silicone, calcium and potassium. The molecular analysis showed that copper occurred in the form of malachite. The remaining elements ( $\mathrm{Si}, \mathrm{K}, \mathrm{Ca}$ ) were parts of silicate and aluminosilicate compounds, which occur in the lithosphere. The presence of iron might be explained in the same way, as it is the fifth most common element in the Earth's crust (Bielański 1976, 590) and is detected in many archaeological finds. The artefacts deposited in the ground are contaminated not only with corrosion but also with soil. The sample containing mixed coin corrosion layer displayed a slightly greater "purity", which was observed through significantly weaker iron signals and lack of potassium and calcium. At the same time, copper and silver signals were much more intense. Quantitatively the intensity of copper in this sample compared to the copper in the ceramic base was ca 3.5-4 times greater.

To summarize, the results of the spectroscopic and microscopic analyses allow for a conclusion that with great probability in both of the ceramic vessels metal items made of copper and silver alloy were deposited. Considerably smaller amount of silver results from its properties, as it oxidizes and penetrates the corrosion layer later than copper. Items from the archaeological contexts contaminated with soil are featured with stronger analytical signals of copper (which is usually associated with the occurrence of malachite). The XRF identification of copper (in both of the vessels) and silver (in vessel No. 1) constitutes also a strong evidence. Additionally, the molecular analysis identified malachite in the sample taken from the inner surface of ceramic vessel No. 1, which has also examined by means of infrared spectroscopy and XRD.

The archaeometric studies of the vessels found in the hoard confirm the chronology of the Prague groschen determined by the numismatic analysis, as well as the chronology of the ceramic containers obtained through the observation if their technological and stylistic features. They prove also that the assemblage is complete and the containers and coins compatible. The research method developed for the purpose of this study might be useful in identification of accidental archaeological finds - especially coin hoards deposited in vessels.

\section{Acknowledgements}

The research is financed by the National Science Centre's OPUS 11 programme, No. UMO-2016/21B/HS3/01030; project title - The hoard of Prague groschen from Watbrzych area; project leader prof. Borys Paszkiewicz. The authors would like to express their gratitude to Bogdan Miazga who developed the 3D model of the vessels and interpreted the obtained data. The publication costs of this article were partially covered by the Estonian Academy of Sciences, the Institute of History and Archaeology at the University of Tartu, and the Institute of History, Archaeology and Art History of Tallinn University. 


\section{References}

Akyuz, S., Akyuz, T., Basaran, S., Bolcal, C. \& Gulec, A. 2007. FT-IR and micro-Raman spectroscopic study of decorated potteries from VI and VII century BC, excavated in ancient Ainos Turkey. - Journal of Molecular Structure, vol. 834-836, 150-153.

Angeli, L., Legnaioli, S., Fabbri, C., Grifoni, E., Lorenzetti, G., Guilaine, J., Palleschi, V. \& Radi, G. 2018. Analysis of Serra d'Alto figuline pottery (Matera, Italy): Characterization of the dark decorations using XRF. - Microchemical Journal, 137, 174-180.

Bielański, A. 1976. Chemia ogólna i nieorganiczna. Warszawa, Państwowe Wydawnictwa Naukowe, 590 .

Boguszewicz, A. 2004. Rozwój kamienicy mieszczańskiej w Dzierżonowie w świetle badań archeologicznych. Dom w mieście średniowiecznym i nowożytnym. Wydawnictwo Uniwersytetu Wrocławskiego, Wrocław, 121-141.

Boguszewicz, A. 2009. Wstęp do archeologii historycznej Dzierżoniowa. Dzierżoniów - wieki minione. "Edytor" Drukarnia-Wydawnictwo, Dzierżoniów, 9-34.

Boguszewicz, A. \& Daszkiewicz, G. 1999. Późnośredniowieczna ceramika z przedmieścia wrocławskiego w Dzierżoniowie. - Śląskie Sprawozdania Archeologiczne, 41, 517-520.

Castelin, K. 1953. Česká drobná mince doby předhusitské a hustiské (1300-1471). Praha.

Genestar, C., Pons, C. \& M'as A. 2006. Analytical characterisation of ancient mortars from the archaeological Roman city of Pollentia (Balearic Islands, Spain). - Analytica Chimica Acta, 557, 373-379.

Giumlia-Mair, A. 2005. On surface analysis and archaeometallurgy. - Nuclear Instruments and Methods in Physics Research, B, 239, 35-43.

Grierson, P. 1975. Numismatics. London.

Hána, J. 2003. Pražské grosé Václava IV. z let 1378-1419. Vlastivědné muzeum Dr. Hostaše v Klatovech v Klatovech, Plzeň.

Karst, D. \& Lasota, C. 2000. Relikty bastei odkryte podczas badań architektoniczno-archeologicznych przy Placu św. Małgorzaty w Świdnicy. - Śląskie Sprawozdania Archeologiczne, 42, 253-268.

Kiersnowski, R. 1958. O tzw. "luźnych" znaleziskach monet wczesnośredniowiecznych w Polsce. Wiadomości Archeologiczne, 25, 181-196.

Kisielewski, J. 1971. Ślady działania prawa Kopernika-Greshama w metrologii groszy praskich, znalezisk odkrytych w Polsce. - Wiadomości Numizmatyczne, R, XV: 2, 65-76.

Mikołajczyk, A. 1977. Naczynia datowane skarbami monet. XIV-XVIII na ziemiach polskich. Wrocław.

Moropoulou, A., Bakolas, A. \& Bisbikou, K. 2000. Investigation of the technology of historic mortars. - Journal of Cultural Heritage, 1, 45-58.

Palmer, R., Raneri, S., Mazzoleni, P., Vella, N. C., Barone, G. \& De Clercq, W. 2018. Neighbourly ties: Characterizing local and Sicilian pottery in post-medieval Malta. - Journal of Archaeological Science: Reports, 19, 575-587.

Pinta, V. 2005. Pražské groše Karla IV (1346-1378). Česká numismatická společnost-pobočka v Chomutově, Chomutov.

Pitarch, A., Queralt, I. \& Alvarez-Perez, A. 2011. Analysis of Catalonian silver coins from the Spanish War of Independence period (1808-1814) by energy dispersive X-ray fluorescence. Nuclear Instruments and Methods in Physics Research, B, 269, 308-312.

Suchodolski, S. 2012. Znaleziska monet i konteksty archeologiczne. Próba klasyfikacji. - Numizmatyka średniowieczna. Ed. S. Suchodolski. Wydawnictwo TRIO, Warszawa, 260-271.

Tabaczyński, S. 1987. Archeologia średniowieczna. Problemy. Źródła. Metody. Cele badawcze. Wrocław, 1987.

Teoh, M. L., McClure, S. B. \& Podrug, E. 2014. Macroscopic, petrographic and XRD analysis of Middle Neolithic figulina pottery from central Dalmatia. - Journal of Archaeological Science, 50, $350-358$. 
Thomas, J. R. \& Wheeler, C. 2002. Methods of Calculating the Capacity of Pottery Vessels. Ashmolean Museum, University of Oxford. http://potweb.ashmolean.org/NewBodleian/11Calculating.html, access 20 April 2017.

Wawrzczak, R. 2017. Sprawa tzw. "Skarbu Tysiąclecia" jako przyczynek do dyskusji na temat przestępczości przeciwko dziedzictwu archeologicznemu. Unpublished master dissertation. Chair of Forensics, Department of Law, Administration and Economy, University of Wrocław.

Beata Miazga, Paweł Milejski, Sylwia Rodak, Alicja Rafalska-Lasocha ja Marta Grzesiak-Nowak

\section{WALBRZYCHI LÄHEDALT LEITUD PRAHA KROSSIAARDES LEIDUVA KERAAMIKA MIKROSKOOPILINE JA SPEKTROSKOOPILINE UURING - KINNITAMAKS KERAAMIKA NING MÜNTIDE KOKKUSOBIVUST}

\section{Resümee}

Juhuslikult leitud Praha krossiaare Wałbrzychi lähedal Alam-Sileesias Poolas on erakordselt põnev leid. Numismaatiline analüüs näitas, et enamik münte oli vermitud Wenceslas IV (1378-1419) valitsusajal: ühtekokku 1310 münti, millest ainult 75 olid vermitud Karl IV (1346-1378) valitsusajal. Wenceslas IV krossid moodustavad 94\% aardest, kuna tema Böömi trooni eelkäija mündid moodustavad vaid 5\%. See näitab selgelt, et aare hoiustati Wenceslase valitsuse teisel poolel, st mitte enne kui 14. ja 15. sajandi vahetusel. Karl IV ja Wenceslas IV ajal (Hána 2003; Pinta 2005) vermitud Praha krosside olemasolevad kataloogid pakuvad Wałbrzychi aarde esialgseks dateeringuks 15. sajandi teise ning kolmanda aastakümne. Kõnealune aare oli hoiustatud kahes keraamilises anumas. See kutsus esile arutluse aarete hulgast leitud keraamiliste anumatega seonduvatest probleemidest. Hiliskeskajal ja uusajal kasutati keraamilisi nõusid tihti väärtuslike esemete, eriti müntide säilitamiseks ning peitmiseks. Keraamiliste anumate tehnoloogiline ja stilistiline analüüs koos numismaatilise analüüsiga võimaldab nende kronoloogiat täpselt määratleda. Otsustamaks, kas münte oli hoitud mingites anumates, viidi läbi arheomeetrilised uuringud, kasutades mittedestruktiivset analüütilist tehnoloogiat. Nendeks olid eeskätt spektroskoopilised meetodid, näiteks XRF- ja XRD-analüüsid, samuti infrapunaspektroskoopia (FTIR). Need tehnoloogiad on arheoloogiliste leidude puhul laialt kasutusel. Mündikogu ja mõlemad anumad mõõdeti meetermõõdustikus ning hinnati ära nende hulk. Keraamiliste anumate puhul viidi läbi ka mikroskoopilised vaatlused.

Mõlema näidise arheomeetrilised andmed näitavad, et mündid olid paigutatud anumatesse. Nende mahutavus oli oluliselt suurem kui üksteise peale asetatud krosside maht. Lisaks anumate sobivale mahutavusele ja müntide söövitusjälgedele nende sees tuvastati vask kui näidiste põhiline koostisosa. Muud tuvas- 
tatud elemendid olid raud, silikoon, kaltsium ja kaalium. FTIR- ja XRD-analüüs näitasid, et vask esines malahhiidi kujul. Ülejäänud elemendid ( $\mathrm{Si}, \mathrm{K}, \mathrm{Ca}$ ) olid silikaadi ja alumiiniumsilikaadi ühendeis, mis esinevad litosfääris. Aardes leitud anumate arheomeetrilised uuringud kinnitavad Praha krosside kronoloogiat, mille määras numismaatiline analüüs, nii nagu ka keraamiliste anumate kronoloogiat, mis tehti kindlaks nende tehnoloogiliste ja stilistiliste omaduste alusel. Samuti tõestati, et kogum on täielik ja anumad ning mündid sobivad kokku. Antud uuringu jaoks arendatud meetod võib osutuda kasulikuks juhuslike arheoloogiliste leidude identifitseerimiseks, eriti anumates peituvate mündiaarete puhul. 